\title{
T25 - Análisis sobre exposición de personas a campos electromagnéticos emitidos por redes celulares desplegadas en ambientes urbanos
}

\author{
Oscar N. Martínez*, Marvin Arias \\ Universidad Nacional de Ingeniería, Nicaragua
}

*Autor al que se dirige la correspondencia: oscar.martinez@fec.uni.edu.ni

\section{Resumen}

$\mathrm{C}^{1}$ despliegue de las redes de telecomunicaciones inalámbricas de tipo móvil en América Latina han tenido un - auge en su implementación en la última década, tales como las redes basadas en los estándares GSM, UMTS, HSDPA, LTE y WiMax son las tecnologías de redes inalámbricas que operan en nuestros países y el resto del mundo creciendo continuamente por la alta demanda de sus servicios. Esto provoca una exposición humana a los campos electromagnéticos (CEM) emitidos por dichas redes cada vez mayor, despertando desconfianza en las personas sobre el posible efecto nocivo de las emisiones electromagnéticas generadas por las antenas de redes celulares, así como el uso del equipo móvil en la salud humana. En este trabajo presentamos los resultados de la simulación desarrollada en Matlab ${ }^{\circledR}$ considerando escenarios extremos de operación para evaluar el cumplimiento de los límites de exposición de personas a CEM provenientes de redes celulares basados en la recomendación UIT-T K52. De los resultados obtenidos comprobamos que debido a la baja potencia de los radiotransmisores de las redes celulares, los tipos de antenas y las bandas de operación $(850,1,900,2,500 \mathrm{MHz})$, la tasa de absorción específica (SAR, por sus siglas en inglés) y la energía absorbida por una persona sometida a exposición de CEM no sobrepasa el $2.1 \%$ y el $4.6 \%$ respectivamente del límite establecido para un emplazamiento. Para un patrón de reuso de $7 / 21$ el SAR es del $7.2 \%$ y la energía es de $13.8 \%$.

Palabras claves: SAR, CEM, UIT-T K52, antenas, radiación

\begin{abstract}
$\mathrm{T}$ The deployment of wireless telecommunications networks mobile kind in Latin America have had a boom in its implementation in the last decade such as networks based on GSM, UMTS, HSDPA, LTE and WiMax standards are technologies of wireless networks operating in our countries and the world continuously growing by the high demand for their services. This causes human exposure to electromagnetic fields (EMF) emitted by these growing networks, arousing distrust in people about the possible harmful effects of EMF from antennas cellular networks and the use of mobile equipment in the human health. In this paper, we present the results of simulation developed in Matlab ${ }^{\circledR}$ considering extreme scenarios of operation to assess compliance with the limits of exposure of people to EMF from cellular networks based on ITU-T K52 recommendation. From the results found that due to the low power radio transmitters of cellular networks, antenna types and operating bands $(850,1900,2500 \mathrm{MHz})$, the specific absorption rate (SAR) and the energy absorbed by a person subject to EMF exposure does not exceed $2.1 \%$ and $4.6 \%$ respectively of the limit for a site. For a $7 / 21$ reuse pattern of the SAR is $7.2 \%$ and energy is $13.8 \%$.
\end{abstract}

Keywords: SAR, EMF, ITU-T K52, antennas, radiation 